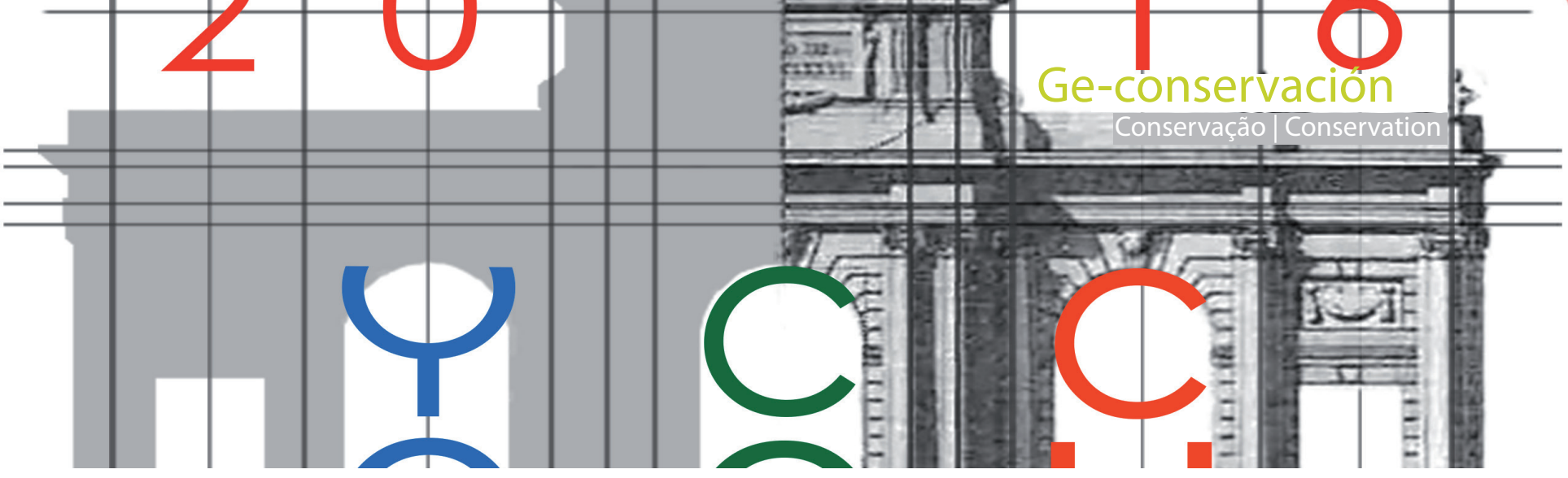

\title{
New insights for creative art processes. Collaboration and experimentation with contemporary artists
}

\author{
Eva Mariana Fuentes Duran, Rita Lucia Amor Garcia, Ma Pilar Soriano Sancho
}

\begin{abstract}
The artists' idea of exploration in new creative fields frequently triggers the collaboration between artists and other professionals. Understanding the experimentation which comes from it is the art restorers and specialists' main duty, as they are forced to establish new standards and increase their knowledge on the use of new materials. Consequently, the communication between artists and restorers is frequent nowadays in the form of interviews but also with practical collaborations. This paper tries to show how productive collaborations can be for artists during the creative process in terms of production and possibilities, and for restorers, because this would be the best way to learn about the art concept and its materiality, which will be helpful for the artwork's future conservation.
\end{abstract}

Key words: conservation, material experimentation, creative process, collaboration, contemporary artists.

\section{Nuevas perspectivas en los procesos artísticos creativos. Colaboración y experimentación con artistas contemporáneos}

Resumen: Las colaboraciones entre artistas y otros profesionales surgen frecuentemente por la tendencia de los primeros a explorar nuevos territorios creativos. La continua experimentación en la creación contemporánea determina la tarea de los restauradores -entre otros-, que se ven forzados a establecer nuevos criterios y a ampliar su campo de estudio a nuevos materiales. Como consecuencia, cada vez es más frecuente la comunicación entre artistas y restauradores, generalmente a través de entrevistas, pero, también, en colaboraciones entre ellos. En este artículo se pretende mostrar cómo de productivas pueden ser las colaboraciones durante el proceso creativo del artista, tanto para este, en términos de producción y ampliación de posibilidades; como para los conservadoresrestauradores, en cuanto a conocer en profundidad el concepto de la obra y los procesos de creación del artista, lo que aportará una valiosa información para la futura conservación de la pieza.

Palabras clave: conservación, experimentación de materiales, proceso creativo, colaboración, artistas contemporáneos.

\section{Introduction}

The contemporary artist has, as one of its main character trails, the firm disbelief in the definition of the limits of Art. Since the beginning of the Avant-gardes in the second half of the $19^{\text {th }}$ Century, the definition of Art has been subjected to the whims of those who called themselves artists. As a result, 'traditional' Art categories have become obsolete in defining the limits for contemporary artists. This can be seen in their experimentation with new materials, methods and techniques during the creative process.

The Spanish artists Patricia Gomez and Maria Jesus Gonzalez are a clear example of this evolution beyond the traditional art boundaries in their artwork since they started working together in 2002. Their artwork is sitespecific in its conception, as it begins in abandoned places from where they aim to salvage the memory of those who inhabited the spaces.

The technique used by these two artists does not steer far from the idea of the traditional Italian detachment process of strappo, first used in the $18^{\text {th }}$ Century. Their use of this centenary method applied to the reality of contemporary materials, presents a challenge to the current conservation methods. This example, that will be further developed in this article, shows the difficult task that art restorers face nowadays with artworks that have been created using heterogeneous materials of unknown composition or taken from outside the artistic range. 


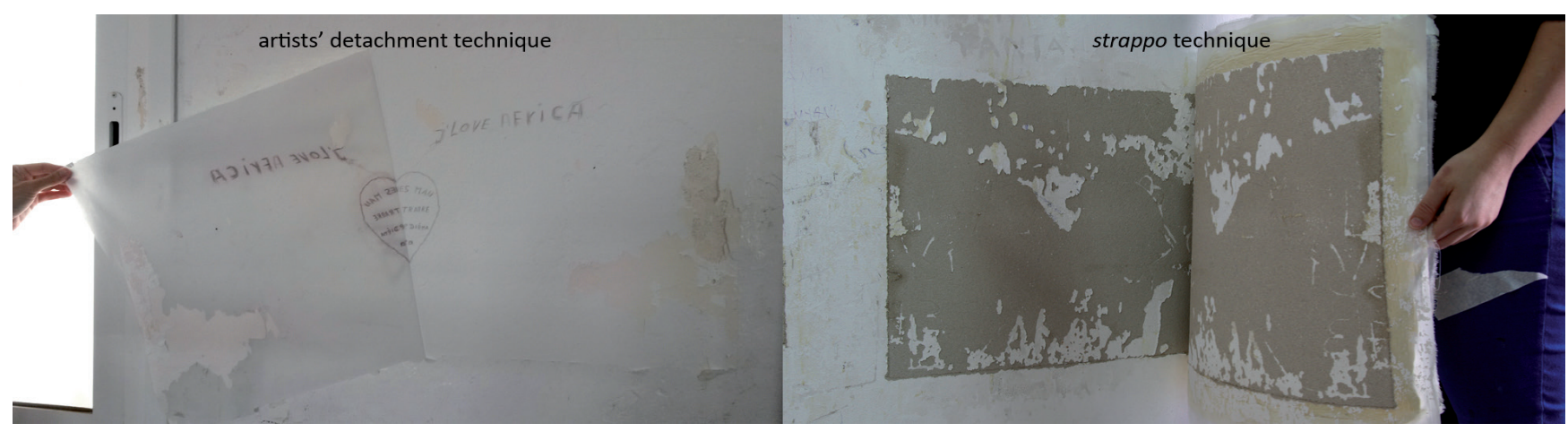

Figure 1.- Comparison between artists' detachment and strappo.

To understand Patricia and Maria Jesus' art practice, it is necessary to explain the differences between the traditional strappo and their method, which they have named 'stamp by detachment'. The strappo is a traditional technique used to preserve wall-paintings, consisting in using animal glue and cotton fabric with the purpose of separating the paint layer from the wall support (Soriano Sancho, 2006). In their adaptation of the technique, Patricia and Maria Jesus mainly use synthetic materials to get a copy, stamp or print - similar to engraving techniques - from those walls that are doomed to disappear (due to the precarious situation of the environments they work at). Combining diverse types of polyvinyl acetate and fabric with particular characteristics - depending on the result they want to get - they extract a representative image of a wall that tells a story.

Furthermore, with their 'stamp by detachment' method, the artists' intention and criteria differ from the restorer's. They do not pursue the loyal conservation of the current (art)work, because during their process they intend to create new artwork from the idea of memory.

Despite some subtleties between the two, the proximity of both processes is clear. Patricia and Maria Jesus find this proximity an enriching one, and they are very interested in understanding the conservation processes. It is thanks to this interest, that it has been possible to develop the interdisciplinary collaboration and study discussed in this paper.

The first collaboration between the artists and the restorers, started as a mere assistance to unload them from a big project. It was while this assistance was taking place, that the two approaches (the artists' and the restorers') blended and learnt from one another into what became a full collaborative proposal.

"À tous les clandestins" (To all the clandestins) is an art project about one of the immigration routes from Africa to Europe, developed in two Immigration Detention Centres in Mauritania and Fuerteventura (Gomez and Gonzalez, 2016). The cells in those two centres, currently laying unused, were covered in drawings and pieces of writing about the trip - dates, numbers, experiences, recommendations, dreams, etc. - from the people who temporarily were detained there. The artists were fascinated by those graphic demonstrations and they decided to keep the immigrants' memory alive by spreading their word and works outside the centres. The project posed a challenge for the artists twofold: in addition to the vast amount of references and writings on the walls in both centres, it soon became apparent that they were to face difficulties in the technical side, that were not going to be easy to solve by themselves.

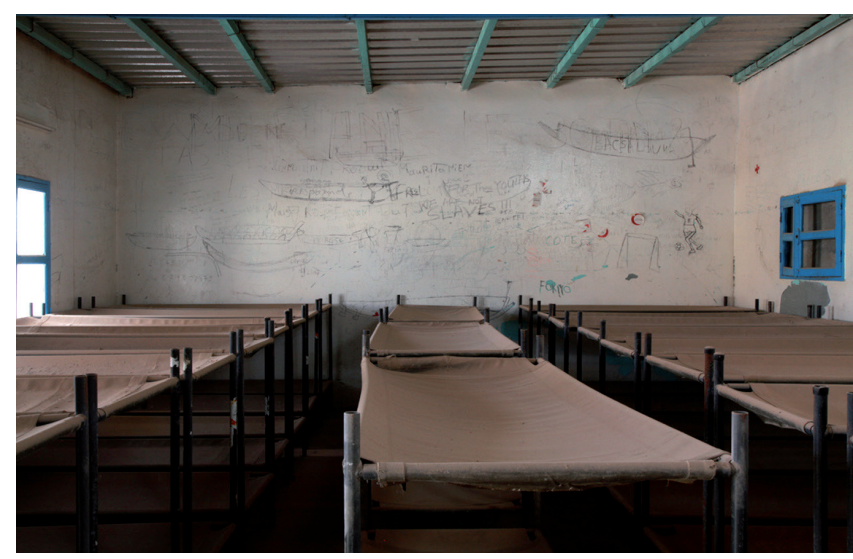

Figure 2.- Walls at CIE Mauritania.

In April 2014, the artists welcomed the team of restorers into their practise, to assist on the technical aspects and lend a hand due to the size of the project. Within the first weeks of collaboration, as the artists' knowledge of the methods of restoration widened, - cleaning, and consolidation among others - they became more interested in the traditional technique of strappo and the possibilities of its application in their art practice. Furthermore, the restorers became more engaged in the creative process, enriching their knowledge in a way that would have never been possible in the conservation lab.

From then on, the two techniques - strappo and 'stamp by detachment' - were used simultaneously within the project. That brought an ongoing exchange of ideas and information that allowed the art production and the comprehension of the artists' creative practice. 


\section{Object and Method}

During the collaboration in Patricia Gomez and Maria Jesus Gonzalez's project "À tous les clandestins", the restorer's objects and methodology evolved at the same speed as the artists' creative process.

Firstly, the main purpose of the collaboration was to assist the artists in any matter related to the use of materials and to provide answers to problems that might appear during the creative process. However, due to the rising duties of the restorers that took place during that first practical contact with the artists, the objectives became more ambitious. This way, in addition to the assistance, the restorers targeted their new purpose: to collect all the information available about the artists' processes, materials and concepts. This was an easy task as they worked closely with the artists, and helpful for the future conservation of their artworks. At the same time, the restorers had the opportunity to learn about their practical role in this kind of collaborations and identify both their responsibilities and limitations in the art production.

The methodology of the project evolved as the roles of both artists and restorers became more defined. In a first approach, the assistance of the restoration team was offsite, and merely one that could be defined as consultancy, mostly about materials, as they had done in all their past projects. As "À tous les clandestins" developed into a much ambitious proposal, one of the members of the restoration team relocated to Fuerteventura to help the artists on-site.

This on-site assistance developed into a close relationship between the two teams in which the artists decided to experiment with the original strappo technique as they learnt about the possibilities that restoration materials and techniques could give to their artistic practice without diminishing the relation of this new project to their catalogue of previous work.

After the completion of the detachments, the teams went back to the artists' studio to continue their investigation on how to transform the detachments that had been completed with the newly found technique into finalised art-pieces. This research was divided in two parts: a practical experimentation with new materials that could be compatible with both the strappo technique and the artists' requirements, and a study concerning their characteristics and properties. The specific methodologies carried out in each part and the materials used will be explained in detail in the following sections.

\section{Practical Experimentation}

The decision of using the strappo technique in this project increased the restorers' duties. This restoration system needs treatment following the detachment, which involves the application of a new support and the removal of all those natural materials used for the facing (this is a compulsory step in strappo detachments, preceded by treatment of the back, which will offer stability to the piece detached during its new life). The possibilities given by the treatment of the back - reinforcement - were numerous, for that reason, a practical research, parallel to the creative process, had to be organised.

The first aim of this practical experimentation was to get the better combination of support, adhesive and technique to get a cohesive appearance between the pieces obtained with the strappo technique, and those obtained via the artists' technique within the same project, which was the main objective of Patricia and Maria Jesus. Furthermore, and in order to achieve longterm conservation, the restoration team had to choose those materials that could guarantee the best stability over time.

The first phase of the practical experimentation comprised the selection of the fabrics and adhesives to be tested on specimens. These fabrics were a selection of five types of different nature but with a similar appearance of a thin net curtain. In terms of adhesives, three adhesives were considered: two vinyl adhesives used and well-known by the artists, and an acrylic resin, recommended by the restorers. The acrylic resin had similar properties to those adhesives used by the artists but with better conservative properties (Table 1).

Table 1.- Materials selected for First Stage experimentation.

\begin{tabular}{|c|c|c|c|}
\hline \multicolumn{4}{|c|}{ Materials selected for First Stage } \\
\hline \multicolumn{2}{|c|}{ ADHESIVES } & \multicolumn{2}{|c|}{ FABRICS } \\
\hline 1 & Plextol $^{\circledR}$ B500 & A & Nylon I \\
\hline 2 & Vinavil $^{\circledR} 69$ & B & Organza Silk \\
\hline 3 & Rayt $^{\circledR}$ Extra & C & Nylon II \\
\hline \multirow{2}{*}{} & D & Polyester \\
\cline { 3 - 4 } & E & Silk II \\
\hline
\end{tabular}

Once all the fabrics had been pasted to the back side of the specimens, the facing removal was carried out, as this step was compulsory for the evaluation of the results. This step consisted on the removal of the animal glue and cotton fabrics used for the detachment applying wet cellulose poultice. The poultice was a combination of two fibres: Arbocel $^{\circledR}$ BC1000 + Arbocel $^{\circledR}$ BC200 (1:1) moistened in hot water. After the removal of the fabric, the results were presented to the artists. 


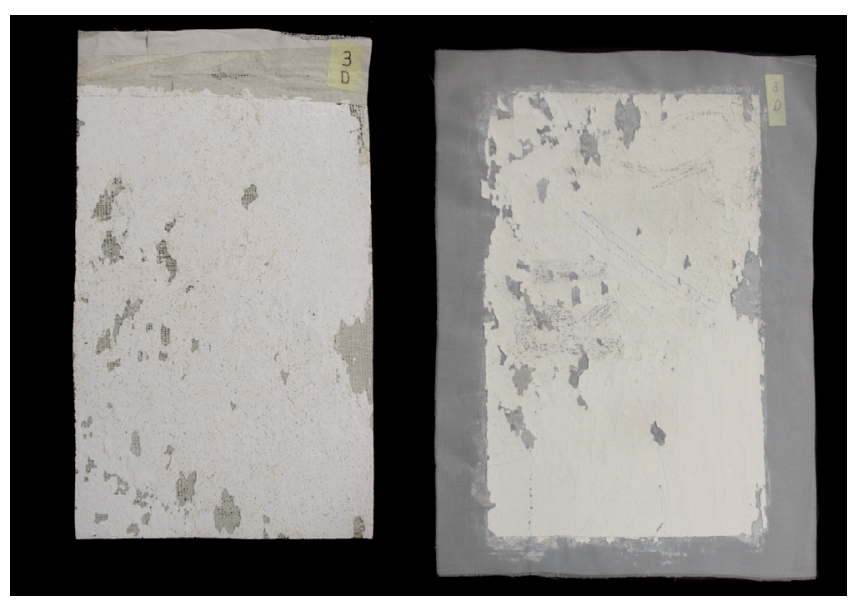

Figure 3.- Specimen process example, First Stage. The same specimen at the beginning (left) and after pasting the polyester fabric with the adhesive Vinavil ${ }^{\circledR} 69$ (right). (Fuentes Duran et al, in press).

Four further stages followed the one just described. The aim of these was to learn more about the specific requirements of the detachments and, in constant exchange with the artists, reach a solution that would imitate the final appearance of the artworks done with their technique.

To understand this experimentation, it is necessary to go back to the dissimilarities between the results that both techniques offer. On the one hand, in the artists' own method, the materials used were a very thin synthetic fabric and polyvinyl acetate, which when dry, showed the image of the detachment from the front when fabric and adhesive became transparent - the layer acted as detachment facing and new support at the same time. On the other hand, the materials used for the strappo facing consisted in animal glue, gauze and cotton fabric, which needed to be removed after the reinforcement from the back - to be able to see what was detached - so the process did not finish after the detachment itself. Whilst the artists' technique showed the artwork from the obverse covered with a transparent layer, the strappo always had a support layer on its reverse.

This difference is key to understand the second stage of the process. Once the strappo detachments were fixed to their supports, there was a need to find a way to mimic the aesthetic qualities of the thin layer of gauze characteristic of the artists' technique. To achieve it, the restorers pasted a thin fabric on the obverse of two tests from the first stage. The fabric used was net curtain - Nylon II - and the adhesives were Plextol $^{\circledR}$ B500 pure and Rayt ${ }^{\circledR}$ Extra (3 parts of adhesive every part of water).

After the results from the second stage were presented, the artists asked for the possibility of giving a mate aspect on the surfaces, so a third stage was developed based on the use of micronized silica that would be added to the adhesive to reduce any shine on the obverse. The micronized silica was mixed with Plextol $^{\circledR}$ B500 - as this had been the most successful during the second stage - in different proportions.
Table 2.- Material tests: Stages 1-3.

\begin{tabular}{|c|c|c|c|c|}
\hline & $\begin{array}{c}\text { STAGE 1 } \\
\text { (textile on reverse) }\end{array}$ & $\begin{array}{c}\text { STAGE 2 } \\
\text { (textile on obverse) }\end{array}$ & \multicolumn{2}{|c|}{$\begin{array}{c}\text { STAGE } 3 \\
\text { (matte obverse) }\end{array}$} \\
\hline & (Textile + Adhesive) & (Nylon II + Adhesive) & \multicolumn{2}{|c|}{$\begin{array}{c}\text { (Nylon II + Adhesive + } \\
\text { Matting agent) }(* *)\end{array}$} \\
\hline $1 \mathrm{~A}$ & Nylon I + Plexto1] B500 & _- & \multicolumn{2}{|c|}{ - } \\
\hline $1 \mathrm{~B}$ & Organza Silk + Plextol@ B500 & _- & \multicolumn{2}{|c|}{ _- } \\
\hline 1C & Nylon II + Plextol@ B500 & Nylon II + Rayt@ Extra & \multicolumn{2}{|c|}{ - } \\
\hline 1D & Polyester + Plextol@ B500 & Nylon II + Plextol@B B500 & \multicolumn{2}{|c|}{-} \\
\hline $2 \mathrm{~A}$ & Nylon I + Rayt@ Extra & - & \multicolumn{2}{|c|}{-} \\
\hline $2 \mathrm{~B}$ & Organza Silk + Rayt $\mathbb{B}$ Extra & - & \multicolumn{2}{|c|}{-} \\
\hline \multirow{2}{*}{$2 \mathrm{C}$} & \multirow{2}{*}{ Nylon II + Rayt@ Extra } & \multirow[b]{2}{*}{ - } & \multicolumn{2}{|c|}{ Plextol@ B500 $(50 \%)+$ Silica } \\
\hline & & & $2: 1$ & 1:1 \\
\hline 2D & Polyester + Rayt $\mathbb{B}$ Extra & - & & \\
\hline \multirow{2}{*}{$3 \mathrm{~A}$} & \multirow{2}{*}{ Nylon I + Vinarild 69} & \multirow{2}{*}{ - } & \multicolumn{2}{|c|}{ 2x Plextol@ B500 (50\%) + Silica } \\
\hline & & & 2:1 & $1: 1$ \\
\hline \multirow{2}{*}{ 3B } & \multirow{2}{*}{ Organza Silk + Vinavil@ 69} & \multirow{2}{*}{ - } & \multicolumn{2}{|c|}{ Plextol $『$ B500 (pure) + Silica } \\
\hline & & & $3: 1$ & $2: 1$ \\
\hline $3 \mathrm{C}$ & Nylon II + Vinavil@ 69 & - & \multicolumn{2}{|c|}{-} \\
\hline 3D & Polyester + Vinavi1@ 69 & - & \multicolumn{2}{|c|}{-} \\
\hline 4 & Silk II + Plestol@ B500 & - & \multicolumn{2}{|c|}{-} \\
\hline 5 & Nylon II + Plextol@ B500 (*) & _- & \multicolumn{2}{|c|}{ - } \\
\hline
\end{tabular}

Following the idea of reproducing the artists' imagery, the fourth stage consisted in the removal of the reverse fabric after a new fabric had been pasted on the obverse. This was possible thanks to the use of different polarity adhesives, similar to chemical intervention layers (Regidor Ros, 2011:526). The reinforcement of the back had been done with a non-polar adhesive, and after the facing removal, a polar adhesive was glued to the new fabric on the front, allowing the removal of the back layer with a non-polar solvent without damaging the front one. The materials tested were Regalrez ${ }^{\circledast} 1094$ in Ligroin (non-polar) with net curtain on the reverse, and Plextol ${ }^{\circledR}$ B500 (polar) with Nylon II for the obverse.

The fifth and last stage was based on some tests made in order to increase opacity in missing parts - where strappo had been unable to perform the detachment. The process was developed in a new specimen in which the reinforcement adhesive of the back was mixed with an inorganic aggregate. Plextol ${ }^{\circledR}$ B500, Nylon II and micronized silica were combined in different proportions with titanium powder as aggregate. The main purpose was to copy the colour and opacity of the background paint where the writings and drawing were located.

\section{Theoretical Research}

The restorers' duties in this art project ended with the theoretical study research made in support of the practical experimentations, in order to evaluate the materials tested from different perspectives. The process carried out to identify the compatibility between the 
materials used, their adequacy regarding the artists' idea and the artwork's future conservation has been the following:

The first and most important aspects to be considered were the objectives and conditions proposed by the artists. Within this reality, there was also the concern for the issues regarding the artworks conservation, field of knowledge of the restorers. Both aspects were highly dependent on the following variables: the results sought, the properties of the materials found and used - and their analysis - and the vulnerability to alterations of the tests.

Secondly, this information was analysed and registered in order to determine the best way forward in the development of the project taking into account both the needs of the artists and the realities of the future life of the artworks. Accomplishing this valuation was the most complex aspect, partly because of the uncertainty of the project, and partly because of the duality of the criteria - artists' and restorers' - which would come into play at the same time.

The method used to face this problem was an adaptation of the process employed at Risk Assessment and Risk Management originally suggested by Robert Waller for the Preventive Conservation Plans (1994). This was adapted to the creative process, as it is showed in Table 3 , which outlines the main ideas of the approach. It seems necessary to highlight that the process ended with the elaboration of a risks ranking that we hope will help in the decision making regarding the properties and alterations to be taken into account, based on their relevance.

Thirdly, once the most relevant properties and their relationship with the imposed conditions and objectives were established, the particular qualities of each material were compared (Fuentes Duran, 2015: 163-165, 170, 177). Through this method, there was an in-depth analysis of similar materials and a very specific determination of the suitability of one over another.

Table 3.- Risk Assessment system during creative processes.

\begin{tabular}{|c|c|}
\hline \multicolumn{2}{|c|}{ Risk Assessment system during creative processes } \\
\hline 1 About the project & $\begin{array}{l}\text { Get information on: } \\
\text { - Materials } \\
\text { - Objectives and artist's priorities (quantify importance) } \\
\text { - Link purposes with material properties }\end{array}$ \\
\hline 2 Present risks & $\begin{array}{l}\text { - Identification and selection of the most important ones } \\
\text { - Causes and consequences }\end{array}$ \\
\hline $\begin{array}{l}3 \text { Analyse and quantify } \\
\text { risks }\end{array}$ & $\begin{array}{l}\text { - When could it happen? } \\
\text { - Possible causes, process and effects } \\
\text { - Influencing factors: } \\
\text { - preventive facts, improvements } \\
\text { - those which could worsen the situation } \\
\text { - Risk quantification, depending on: } \\
\text { - Probability } \\
\text { - Consequences } \\
\text { - Recoverability }\end{array}$ \\
\hline $4 \quad$ Establish priorities & Ranking of risks \\
\hline
\end{tabular}

\section{Results and Discussion}

In the first stage, the practical research did not present remarkable differences between the visual aspect of the diverse combinations tested. However, despite the results of the organoleptic analysis being unremarkable, the following theoretical research showed clear choices for both the adhesive and the fabric.

During the theoretical study, the restauration team had determined that Plextol $^{\circledR}$ B500 presented a better future conservation of the tests - in comparison to the vinyl adhesives proposed by the artists. Also, as far as the fabric was concerned, synthetic fabrics were recommended over natural ones, and the net curtain so-called Nylon II as the best option for the artists. Despite polyester fabrics showing slightly better characteristics for the restorers, the Nylon II was chosen because it adapted well and was wellknown by the artists.

Following the theoretical study, and as previously determined in this article, an agreement was reached between the two teams, and the final materials were, the adhesive recommended by the restorers, Plextol $^{\circledR}$ B500, and the Nylon II, which the artists knew and had used previously.

As for the results in second, third and fourth stages, the approach was that of analysing the tests as they came, and from them have a conversation with the artists, to agree on a next stage. The conclusions and findings of each one determined new corrections to be introduced in the next stages, in order to get the aesthetic form sought.

However, and as part of their creative process, the artists eventually decided to abandon the aim of mimicking their own technique as they became more and more interested in what they believed were the aesthetic characteristics of the original strappo detachments. Furthermore, the results given by Regalrez ${ }^{\circledR} 1094$ in the fourth stage were unsatisfactory, presenting a lack of adherence that caused weakness in the artwork - in addition to the toxicity that Ligroin offered. Finally, the results given in the fifth stage were not aesthetically pleasing to the artists. This further reinforced their idea of going back to the results of the first stage to keep the appearance that strappo technique offered in the artworks.

\section{Conclusions: understanding the importance of colla- borations}

The restorers' role in this collaboration has been much more significant and influential than first thought. From just being witnesses during the 'creative moment' alongside the artists, firstly as mere observers seeking information about their artwork, to a later much more active role, giving advice and solutions to new possibilities, the restorers have carried out an experimentation in order to obtain empirical results to be applied in a creative environment. 
The theoretical analysis carried out by the restorers, was aimed at the artists, in order to give them different visual options. Restorers were, at the same time, doing their own research to be able to objectively expose why they believed some materials were more suitable than others.

All this work, in addition to the easing and accelerating of the artists' production, has increased the restorers' knowledge of these artworks, not only on their physical aspect, but also the conceptual one - meaning, values and artists' intention - and it adds a great value to the restorers' task.

Images are the authors' otherwise stated.

\section{Bibliography}

FUENTES DURAN, E. (2015). La colaboración entre artista y restaurador durante el proceso creativo. Reflexiones a partir de una experiencia. [Master Dissertation online]. Valencia. Universitat Politècnica de València. Available at: http://hdl.handle. net/10251/62111 [Accessed 26 April 2016]
FUENTES DURAN, E.; AMOR GARCIA, R.; SORIANO SANCHO, P. (In Press). New insights for creative art processes. Collaboration and experimentation with contemporary artists. In: 5th International Conference Youth in Conservation of Cultural Heritage YOCOCU 2016 Congress Book. Madrid: MNCARS.

GOMEZ, P.; GONZALEZ, M.J. (2016). Patricia Gómez y Maria Jesús González website. [online] Available at: http://www.patriciagomezmariajesusgonzalez.com/ [Accessed 22 July 2016]

REGIDOR ROS JL, et al. (2011). Puesta en práctica de soluciones propuestas para las pinturas arracadas de Palomino en la Iglesia de Los Santos Juanes de Valencia. In $18^{\text {th }}$ International Meeting on Heritage Conservation. Granada: Universidad de Granada, pp. 524-27.

SORIANO SANCHO, P. (2006). Traslado a Nuevos Soportes De Pinturas Murales Arrancadas, CD-ROOM. Valencia: Editorial UPV.

WALLER, R. (1994). Conservation risk assessment: a strategy for managing resources for preventive conservation. In: Preventive conservation practice, theory and research: preprints of the contributions to the Ottawa congress. London: IIC. pp. 12-16.

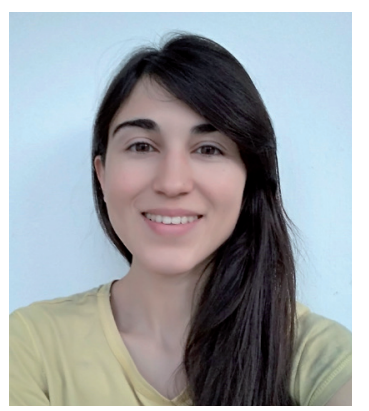

\section{Eva Mariana Fuentes Duran}

evafuentesdurann@gmail.com

Graduated in Art History at Salamanca University, and postgraduate in Art Conservation and Restoration by Polytechnic University of Valencia (UPV). Her research is focused on collaborations with artists and nowadays she is collaborating with the artists Patricia Gomez and M. Jesus Gonzalez in the processes related with detachment of wall-paintings. 


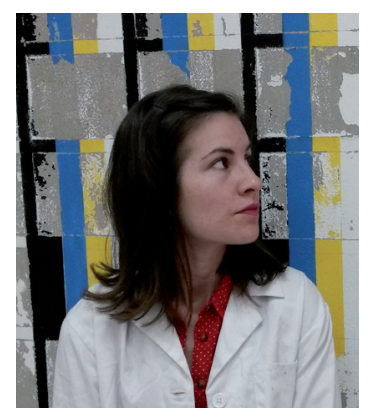

\section{Rita L. Amor Garcia}

rita@cons-graf.com

Ph.D. Candidate in Science and Restoration of Historic and Artistic Heritage program (UPV) studying the adaptation of strappo in aerosol art. She has participated in diverse researching projects in conservation of wall-paintings, including the collaboration with Patricia Gomez and M. Jesus Gonzalez. Also, she is a member of GElIC Urban Art Working Team.

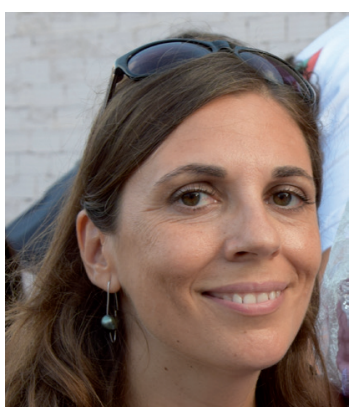

\section{Ma Pilar Soriano Sancho}

pisosan@crbc.upv.es

Doctor in Fine Arts by the Polytechnic University of Valencia, professor at the Art Conservation and Restoration Department and member of Institute of Heritage Restoration, UPV. She has collaborated in a wide range of researching projects. Her researching field is the conservation of mural painting, focused in detached wall-paintings and new supports. 